\title{
Plant regeneration from direct and indirect organogenesis and assessment of genetic fidelity in Saccharum officinarum using DNA-based markers
}

\author{
Avinash S. Thorat ${ }^{1,2 *}$, Nishant A. Sonone ${ }^{1}$, Vrushali V. Choudhari', Rachayya M. \\ Devarumath ${ }^{1}$ and K. Harinath Babu ${ }^{1}$ \\ ${ }^{1}$ Molecular Biology \&t Genetic Engineering Section, Vasantdada Sugar Institute, Manjari (Bk),Pune, \\ Maharashtra, India \\ ${ }^{2}$ Department of Botany, Shivaji University, Kolhapur, Maharashtra, India
}

\section{ABSTRACT}

Sugarcane has acquired significant importance in the world economy because of the sugar and ethanol production. Therefore, rapid multiplication of outstanding sugarcane variety is necessary in developing countries. The aim of this investigation was to compare regeneration efficiency of various explants and genetic fidelity of regenerated plantlets certified by using DNA-based molecular markers, that is, random amplified length polymorphism (RAPD) and inter simple sequence repeats (ISSR). The sugarcane plantlets were obtained through direct (axillary buds, apical meristem, and leaf whorl disk) and indirect (callus culture) shoot organogenesis from the variety Co 86032. Among all the explants, highest shoot forming ability was observed in axillary buds showed $97.66 \pm 0.66 \%$ shoot formation and the highest number of shoots per explants $(4.33 \pm 0.24)$ and a total number of regenerated shoots $(173.00 \pm 8.11)$ were observed in the leaf whorl disk. Morphological variation was not observed among the regenerated plants from various explants and therefore, genomic DNA was isolated from fresh leaves and genetic fidelity assessment was carried out using RAPD and ISSR. Both the markers produced 1368 and 2271 bands, respectively, including all the tested plants, indicates that plants derived from direct organogenesis did not show any polymorphism. However, a genetic variation has been observed in the plants derived from callus and showed 4.54\% polymorphism during analysis. The results suggested that plants regenerated from direct organogenesis are of more true-to-type, whereas genetic variation occurs during indirect organogenesis. Combination of RAPD along with ISSR can be used for detection of genetic variation in the early stage in sugarcane micropropagation. High performance of regeneration and low risk of genetic variation ascertains the efficiency of this operation.

KEY WORDS: FIDELITY, ISSR, MICROPROPAGATION, REGENERATION, RAPD, SUGARCANE

ARTICLE INFORMATION:

*Corresponding Author: avinashthorat.vsi@gmail.com

Received $19^{\text {th }}$ Jan, 2018

Accepted after revision $20^{\text {th }}$ March, 2018

BBRC Print ISSN: 0974-6455

Online ISSN: 2321-4007 CODEN: USA BBRCBA

$\therefore$ Thomson Reuters ISI ESC / Clarivate Analytics USA and

Crossref Indexed Journal

NAAS Journal Score 2017: 4.38 SJIF 2017: 4.196

(1) A Society of Science and Nature Publication, Bhopal India

2018. All rights reserved.

Online Contents Available at: http//www.bbrc.in/

DOI: $10.21786 / \mathrm{bbrc} / 11.1 / 9$ 


\section{INTRODUCTION}

Sugarcane (Saccharum officinarum L.) is a member of the Poaceae family and is an imperative cash crop. Sugarcane produces around $70 \%$ to $80 \%$ of sugar worldwide and 100\% in India (Suprasanna et al. 2011; Thorat et al. 2017). In India, sugarcane is cultivated under a wide range of agro-climatic conditions and secured a distinct position after cotton, and as an agro-industrial crop because of the prominent source of efficiently vital product (sugar) as well as by-products (bagasse, molasses, and press mud) playing a major role in the economic progress of small and large-scale industrial sectors. In a tropical climate, the cultivation of sugarcane is more successful in terms of cane yield and sugar recovery throughout the year (Thorat et al. 2015; Singh and Shami, 2017).

Sugarcane is recognized as the most competent crop, which converts solar energy into harvestable chemical energy in the form of sucrose and biomass (Joyce et al. 2010). Sugarcane varieties are highly heterogeneous and usually multiplied by stem cutting method. The stems of sugarcane with two to three nodes are generally used for plantation in many tropical countries (Behara and Sahoo, 2009). Owing to the unavailability of standardized multiplication procedure and contamination by systematic microorganism is the serious challenge to multiply an elite genotype of sugarcane (Lal and Singh, 1994; Thorat et al. 2016).

However, plant tissue culture of sugarcane has received extensive research attention because of its economic consequence (Behara and Sahoo, 2009). During the past four decades, plant tissue culture is used for the large-scale micropropagation in commercial horticulture and agriculture worldwide (Das et al. 1996). Generally, plant tissue culture technique is used for providing the highest number of healthy plantlets within the short duration, which is useful for rapid spreading of newly, released sugarcane varieties in short duration (Fildmann et al. 1994). In sugarcane, various explants like apical meristem (Devarumath et al., 2007), axillary buds (Thorat et al. 2016), leaf whorl disk (Gill et al. 2006; Kaur et al. 2015), callus (Behara and Sahoo, 2009), and cell suspension culture (Thorat et al. 2017) were used for rapid multiplication. During the process, to maintain genetic fidelity of the micro-propagated plantlets with respect to the mother plants are major concerns. Despite the advantages of micropropagation, many genera including sugarcane has been found polymorphic,(Devarumath et al., 2007; Lal et al. 2007, Rizvi et al, 2012 and Thorat et al. 2017).

Since last few years, a range of DNA-based molecular markers have been utilized for fast and recognizable assessment of the genetic similarity of micropro- pagated plants including sugarcane (Devarumath et al., 2002 and 2007; Lal et al. 2007; Goel et al. 2009; Rizvi et al, 2012; Kshirsagar et al. 2015). The random amplified length polymorphism (RAPD) and inter simple sequence repeats (ISSR) are easy, reliable, quick technique to perform, it did not require past knowledge of the nucleotide sequence of the organism, and requisite less amount of DNA as well as comparatively less expensive and provides effective variation at multiple loci in DNA (Williams et al. 1990; Ceasar et al. 2010 Govindraj et al. 2015).The present work was performed with an objective to establish the rapid and efficient micropropagation method by using various types of sugarcane explants, and study their genetic variation occurred during the process of direct and indirect organogenesis using molecular markers (RAPD and ISSR).

\section{MATERIAL AND METHODS}

The sugarcane var. Co 86032 grown in experimental farms of Vasantdada Sugar Institute, Manjari (Bk.), Pune, Maharashtra, India was used in this investigation. The plants were regenerated from direct (axillary buds, apical meristem, leaf whorl disk) and indirect (callus) organogenesis.

\section{DIRECT ORGANOGENESIS}

\section{Axillary buds culture}

The axillary buds were collected from 6 to 8-month old field-grown sugarcane. The sugarcane were sets cleaned properly by washing under running tap water followed by $0.1 \%$ Tween-20 solution for $15 \mathrm{~min}$. After choosing 50 healthy axillary buds, were dissected properly (1-1.5 $\mathrm{cm}^{2}$ ) with the help of scalpels and kept in antioxidant solution (0.1\% citric acid and $0.1 \%$ ascorbic acid) for 15 min followed by surface sterilized with Bavistin ${ }^{\mathrm{Tm}}$ $(0.1 \%)$ and streptomycin $(0.1 \%)$ for $15 \mathrm{~min}$ at $25 \pm 1^{\circ} \mathrm{C}$ (Thorat et al. 2016). Sterilized buds were inoculated in primary shoot regeneration medium supplemented with sucrose $(30 \mathrm{~g} / \mathrm{l})$, casein hydrolysate $(0.5 \mathrm{~g} / \mathrm{l})$, polyvinyl pyrrolidone-40 (100 mg/l), inositol $(20 \mathrm{mg} / \mathrm{l})$, thymine (1 mg/l), and 6-benzylaminopurine (BAP) (3 mg/l) containing $0.5 \%$ plant preservative mixture and incubated at $28 \pm 1^{\circ} \mathrm{C}$ with a $16 \mathrm{~h}$ photoperiod for 1 month (Thorat et al. 2016).

\section{Apical meristem culture}

The apical meristems were excised from 4 to 5-month old field-grown sugarcane tops. The cane tops were surface sterilized with the above mentioned procedure. In total, 50 number of apical meristem was obtained by removing the outer layers and the innermost part (2-3 
$\mathrm{mm})$ were aseptically transferred to test tubes containing Murashige and Skoog (1962) basal (MS) medium supplemented with kinetin and BAP (Sawant and Tawar, 2011) and allowed to grow for 20-30 days.

\section{Leaf whorl disk culture}

Expanded leaves from the harvested shoot tops were removed and washed with $0.1 \%$ Teepol $^{\mathrm{TM}}$ for 4-5 min followed by a rinse under tap water for 10-12 min. The external whorls of mature leaves were removed till a spindle of $8-10 \mathrm{~cm}$ in length and $\sim 1.0 \mathrm{~cm}$ in diameter was obtained (Kalunke et al. 2009; Babu and Nerkar, 2012). Then these spindle explants were treated with $70 \%$ ethanol for $30 \mathrm{sec}$ followed by $0.1 \%$ Bavistin $^{\mathrm{TM}}$ and $0.1 \%$ streptomycin for $15 \mathrm{~min}$, then surface sterilized with $0.1 \% \mathrm{HgCl}_{2}$ for $20 \mathrm{~min}$. These sterilized explants were washed thrice with sterile distilled water to remove the traces of $\mathrm{HgCl}_{2}$. After surface sterilization treatment, leaf whorls were washed thoroughly in sterilized distilled water for 3-4 times and external layers of leaf sheath were pulled out one by one until the cylinder reached approximately $0.5-1 \mathrm{~cm}$ in diameter. The 50 cylinders were cut transversely into thin slices (1-1.5 mm thick) and inoculated on MS medium supplemented with 5.0 $\mathrm{mg} / \mathrm{l}$ naphthaleneacetic acid (NAA) with $0.5 \mathrm{mg} / \mathrm{l}$ kinetin (Kaur and Sandhu, 2015). About 30 explants were taken per treatment and number of replications per treatment was three. The cultures were incubated under light ( $3000 \mathrm{Lux})$ at $26 \pm 2^{\circ} \mathrm{C}$ and $16 / 8 \mathrm{~h}$ (light/dark) photoperiod regimes.

\section{INDIRECT ORGANOGENESIS}

\section{Callus culture}

The thin slices (1-1.5 mm thick) of the leaf whorl after sterilization (above mention), inoculated on callus induction medium containing MS basal medium supplemented with sucrose $(20 \mathrm{~g} / \mathrm{l})$, coconut water $(100 \mathrm{ml} / \mathrm{l})$, polyvinylpyrrolidone-40 (PVP) (500 mg/l), casein hydrolysate (500 mg/l), 2-ethanesulfonic acid (MES buffer) (500 mg/l), thiamine $\mathrm{HCl}(1 \mathrm{mg} / \mathrm{l})$, inositol $(20 \mathrm{mg} / \mathrm{l})$, and proline $(500 \mathrm{mg} / \mathrm{l})$ were incubated in dark at $28 \pm 2^{\circ} \mathrm{C}$ for 2 weeks. Well proliferated 50 embryogenic calli $\left(0.5 \mathrm{~cm}^{2}\right)$ were transferred to shoot regeneration medium.

\section{Shoot multiplication}

After 1 month-inoculation, regenerated shoots from various explants were isolated without damaging their basal portion. Single shoot or shoots clusters were transferred to culture bottles containing secondary shoot multiplication medium containing liquid MS basal medium supplemented with $30 \mathrm{~g} / \mathrm{l}$ sucrose, $0.5 \mathrm{~g} / \mathrm{l}$ casein hydrolysate, $100 \mathrm{mg} / \mathrm{l} \mathrm{PVP,} 20 \mathrm{mg} / \mathrm{l}$ inositol, $1 \mathrm{mg} / \mathrm{l}$ thiamine $\mathrm{HCl}, 1 \mathrm{mg} / \mathrm{l}$ kinetin, $0.5 \mathrm{mg} / \mathrm{l} \mathrm{NAA}$, and $2 \mathrm{mg} / \mathrm{l}$ 6-ben- zylaminopurine. The culture bottles were incubated at $26 \pm 2^{\circ} \mathrm{C}$ with a $16 / 8 \mathrm{~h}$ (light/dark) photoperiod regimes for 4 weeks on illuminated shakers.

\section{Rooting of shoots and acclimatization}

Elongated shoots $(4-5 \mathrm{~cm})$ after 4 weeks from SSRM were transferred to half-strength MS basal medium supplemented with $0.5 \mathrm{mg} / \mathrm{l}$ NAA. Root induction was promoted by incubated at room temperature for $16 / 8$ h (light/dark) photoperiod regimes. After 15-20 days, shoot showing prominent roots was considered as rooted plantlets. In total, 10-12-weeks old rooted plants were carefully cleaned with water to remove excess agar, then transferred in plastic bags filled with soil mixture containing 1 part of sand, 1 part of the coco peat, and 1 part of vermicompost $(\mathrm{v} / \mathrm{v})$ and irrigated with water for the next 2 weeks under greenhouse condition.

\section{Genetic stability analysis using molecular markers (RAPD and ISSR)}

Total genomic DNA from young leaves of the mother plant and in-vitro raised plants was isolated by the method described by Aljanabi et al. (1999). The quality and quantity of genomic DNA were determined by $0.8 \%$ agarose gel electrophoresis and by UV-vis spectrophotometry. The final concentration of extracted genomic DNA was made to $50 \mathrm{ng} / \mu \mathrm{l}$ and stored at $-20^{\circ} \mathrm{C}$ till further use. Two sets of primers including arbitrary (RAPD) and semi-arbitrary (ISSR) were used for analysis of genomic DNA ofthe mother plant and in-vitro raised plantlets. In total, 10 primers each of RAPD (OPH series, Operon Technologies, INC. California, USA) (Table 2) and ISSR primers (UBC series, University of British Columbia, Vancouver, Canada) (Table 3) were selected on the basis of preliminary screening and their reproducibility. PCR analysis was done with slight modifications (Williams et al. 1990). For RAPD, DNA amplification was carried out with total reaction mixture volume of $20 \mu$ consisting 50 ng template DNA ( $1 \mu \mathrm{l}), 10 x$ PCR buffer with $\mathrm{MgCl}_{2}$ $(2 \mu \mathrm{l}), 250 \mu \mathrm{M}$ dNTPs $(2 \mu \mathrm{l}), 0.25 \mu \mathrm{M}$ primer $(2 \mu \mathrm{l}), 1 \mathrm{U}^{2}$ Taq DNA polymerase $(0.2 \mu \mathrm{l})$, and sterile nuclease-free distilled water (12.8 $\mu \mathrm{l})$. PCR was performed on Thermal cycler (Applied Biosystem, USA) at initial temperature of $94^{\circ} \mathrm{C}$ ( $5 \mathrm{~min}, 1$ cycle), followed by 40 cycles of $1 \mathrm{~min}$ at $94^{\circ} \mathrm{C}, 1 \mathrm{~min}$ at $37^{\circ} \mathrm{C}, 2 \mathrm{~min}$ at $72^{\circ} \mathrm{C}$, and final extension cycle of $10 \mathrm{~min}$ at $72^{\circ} \mathrm{C}$. In the case of ISSR, the reaction mixture was made similar to RAPD. However, PCR was carried out using initial denaturation at $95^{\circ} \mathrm{C}$ for $5 \mathrm{~min}$ followed by 40 cycles $1 \mathrm{~min}$ at $94^{\circ} \mathrm{C}, 1 \mathrm{~min}$ at $50-54^{\circ} \mathrm{C}$ (depending upon the primer), $2 \mathrm{~min}$ at $72^{\circ} \mathrm{C}$, and final extension cycle of $10 \mathrm{~min}$ at $72^{\circ} \mathrm{C}$. The samples were stored at $4^{\circ} \mathrm{C}$ until further analysis was carried out. The PCR products were resolved on $1.5 \%(\mathrm{w} / \mathrm{v})$ agarose gel with $1 \mathrm{x}$ TBE buffer, stained with ethidium bromide and 
documented under UV light. The fragment size was estimated using $1 \mathrm{~kb}$ DNA ladder.

\section{Statistical Analysis}

All experiments were performed twice, with three independent replicates. Genomic DNA was extracted from the same bulk sample to maintain the consistency of results. The data were analyzed using Microsoft Excel 2010 and SPSS (Statistical package for the social sciences; software package version 16). One-way ANOVA (Analysis of variance) was applied to test mean differences of all treatments while the statistically significant difference between mean values was established at $p$ value $\leq 0.05$ while Duncan's New Multiple Range Test was used. The results were expressed as mean \pm SE. For RAPD and ISSR analysis, a band with same mobility were counted as an identical band while each amplified product was scored as present (1) or absent (0), bands of low intensity that were difficult to be distinguished as present or absent were not considered.

\section{RESULTS AND DISCUSSION}

Somaclonal variations have been frequently reported in tissue culture raised plants. The occurrence of variation- during in-vitro propagation is because of the source of explants and the pathway of regeneration (Goto et al. 1998). The present study was conducted to screen invitro plant regenerationin sugarcane from direct (axillary buds, apical meristem, leaf whorl disk) and indirect (callus) organogenesis and to confirm genetic stability, in-vitro regenerated plants were evaluated through RAPD and ISSR markers. Micropropagation protocol for sugarcane was standardized in an earlier report through apical meristem (Sawant and Tawar, 2011), axillary buds (Thorat et al. 2016), direct shoot regeneration from leaf whorl disk (Kaur and Sandhu, 2015) and indirect organogenesis from embryogenic callus (Gill et al. 2004). Shoot formation was observed from all types of explants in sugarcane var. Co86032 and the regenerated shoots were multiplied on SSRM medium. Numbers of regenerated shoots were varied by type of explant and method of regeneration and depicted in Fig. 1 and Table 1.

Observations were taken after 30 days of initial culture. Different explants showed healthy regenerated shoots. Among all types of explants, a number of explants showed shootsformation were observed highest from axillary buds culture $(48.33 \pm 0.33)$ followed by the apical meristem (46.67 \pm 0.88$)$, leaf whorl disk $(40.00 \pm 1.00)$, and lowest in callus $(37.33 \pm 1.76)$. The variation of shoot proliferation in different explant is might be because of

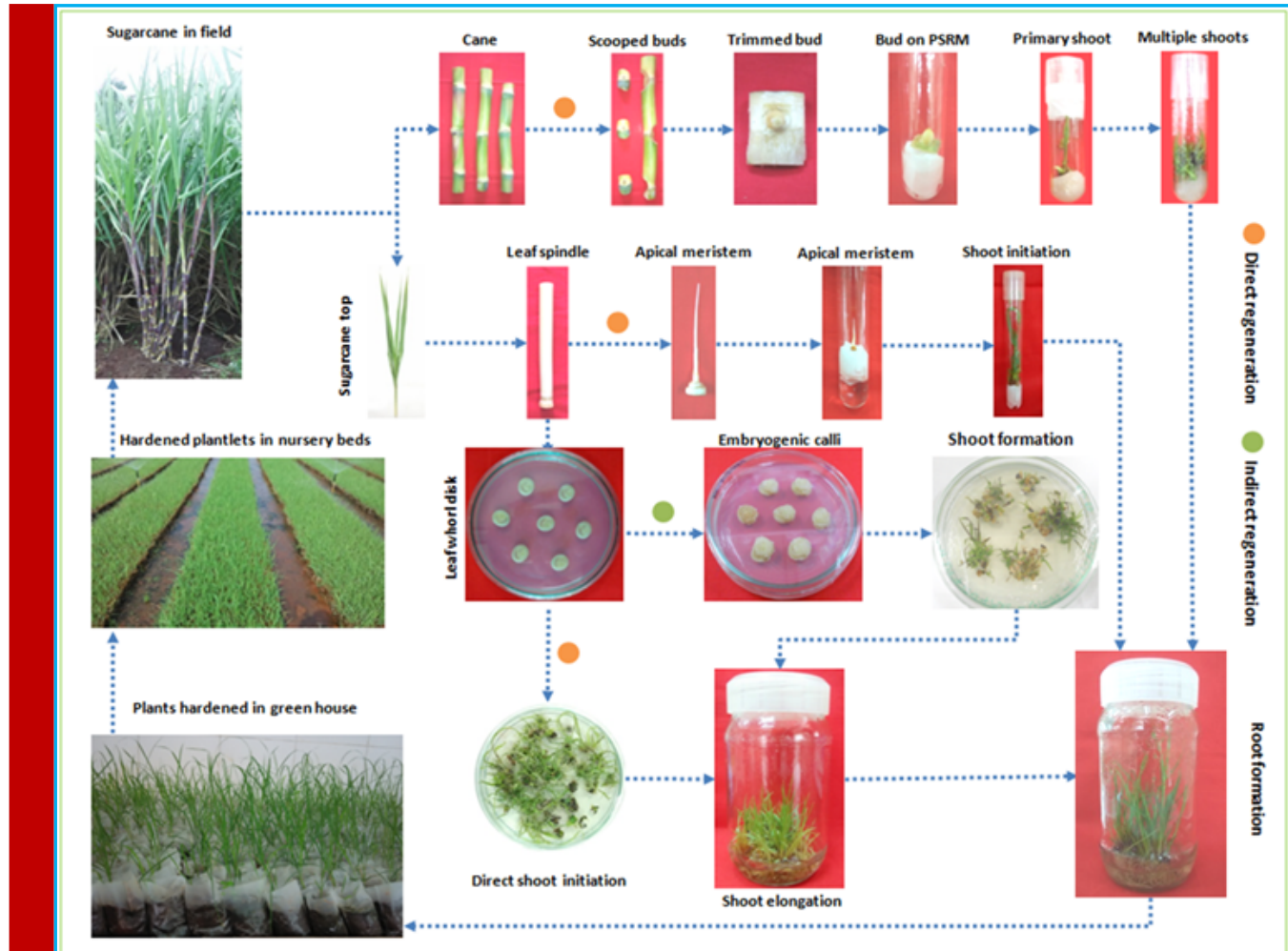

FIGURE 1. Diagrammatic/schematic representation of micropropagation protocol for sugarcane (Saccharum officinarum L.) using direct and indirect organogenesis. 

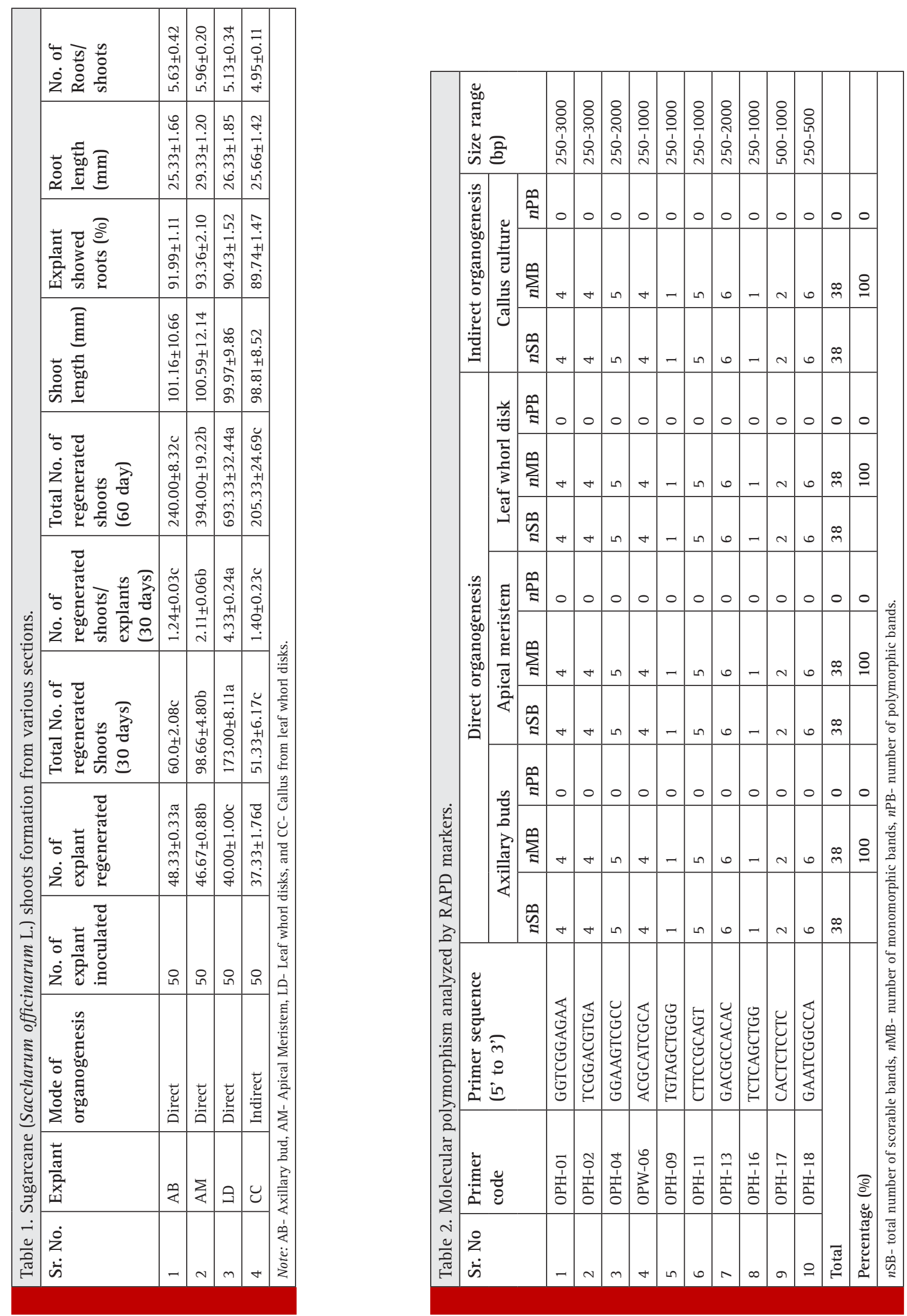


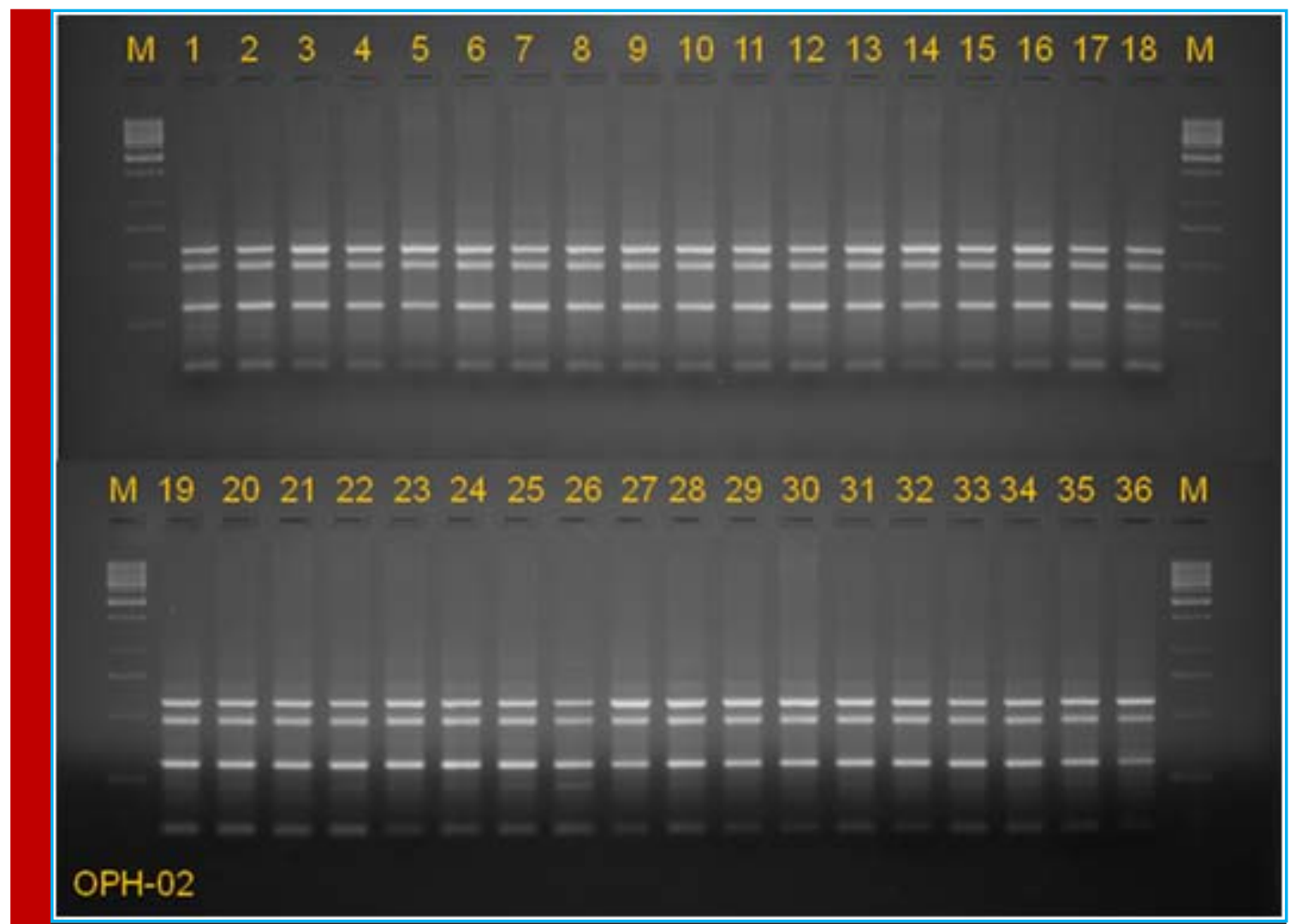

FIGURE 2. RAPD profile of regenerated plantlets from: axillary buds (1-9), callus (10-18), apical meristem (19-27) and leaf whorls (28-36), 1 kb DNA marker (M).

incompatibility of tissue with the nutrients in medium, tissue damage during pretreatment and surface sterilization and moreover inabilities of cells to further re-differentiate into growing tissue (Thorat et al. 2016). However, the number of shoots regenerated from leaf whorl disk was highest $\left(173.00_{ \pm} 8.11\right)$ followed by the apical meristem $(98.66 \pm 4.80)$, axillary buds $(60.00 \pm 2.08)$, and lowest in callus culture $(51.33 \pm 6.17)$. The possibility of variation was because of non-response of explant like browning and development of non-regenerable callus. The highest number of regenerated shoots per explants were observed in leaf whorl disk $(4.33 \pm 0.24)$ followed by the apical meristem $(2.11 \pm 0.06)$, callus from leaf whorl disk $(1.40 \pm 0.25)$, and the lowest was in axillary buds (1.24 \pm 0.03$)$. Similar results were reported in sugarcane variety $\mathrm{CoPb} 91$ and found four shoots per spindle, after 28 days of initial culture of the leaf whorl disk (Kaur and Sandhu, 2015). In apical meristem culture of sugarcane var. HSF-240, CP-77-400, and CPF-237 showed 5.83 shoots per explants after 3 weeks is almost thrice compare to current results. The highest numbers of healthy shoots in terms of shoot length were found in the range from $101.16 \pm 10.66 \mathrm{~mm}$ (axillary buds) to $98.81 \pm 8.52$ $\mathrm{mm}$ (callus culture).
Similar results in terms of shoot length $(105 \mathrm{~mm})$ were observed by Khan et al. (2008) in the various sugarcane cultivars. After 30 days of initial culture, all the regenerated shoots were transferred to SSRM for further multiplication and shoot elongation. It was observed rapid multiplication of shorts in the second subculture and found approximately four times shoot multiplication after 60 days. The highest number of multiple shoots was observed in leaf whorl disk $(693.33 \pm 32.44)$ followed by the apical meristem $(394.00 \pm 19.22)$, axillary buds $(240.00 \pm 8.32)$, and callus $(205.33 \pm 24.69)$. Kaur and Sandhu (2015) found that 448 shoots were regenerated from leaf whorl disk after second subculture (2 months) in sugarcane cultivar $\mathrm{CoPb} 91$. Over a period of 60 days of initial culture, numbers of plants regenerated from direct regeneration were more comparing with indirect regeneration.

All the regenerated shoots after 60 days of culture were transferred to the rooting medium for developing roots. Root formation was observed from almost all the shoots after 2 weeks of culture on rooting medium. In the present investigation, no significant differences were found with respect to the rooting percentage, root length, and number of roots per shoots (Table 1). The 


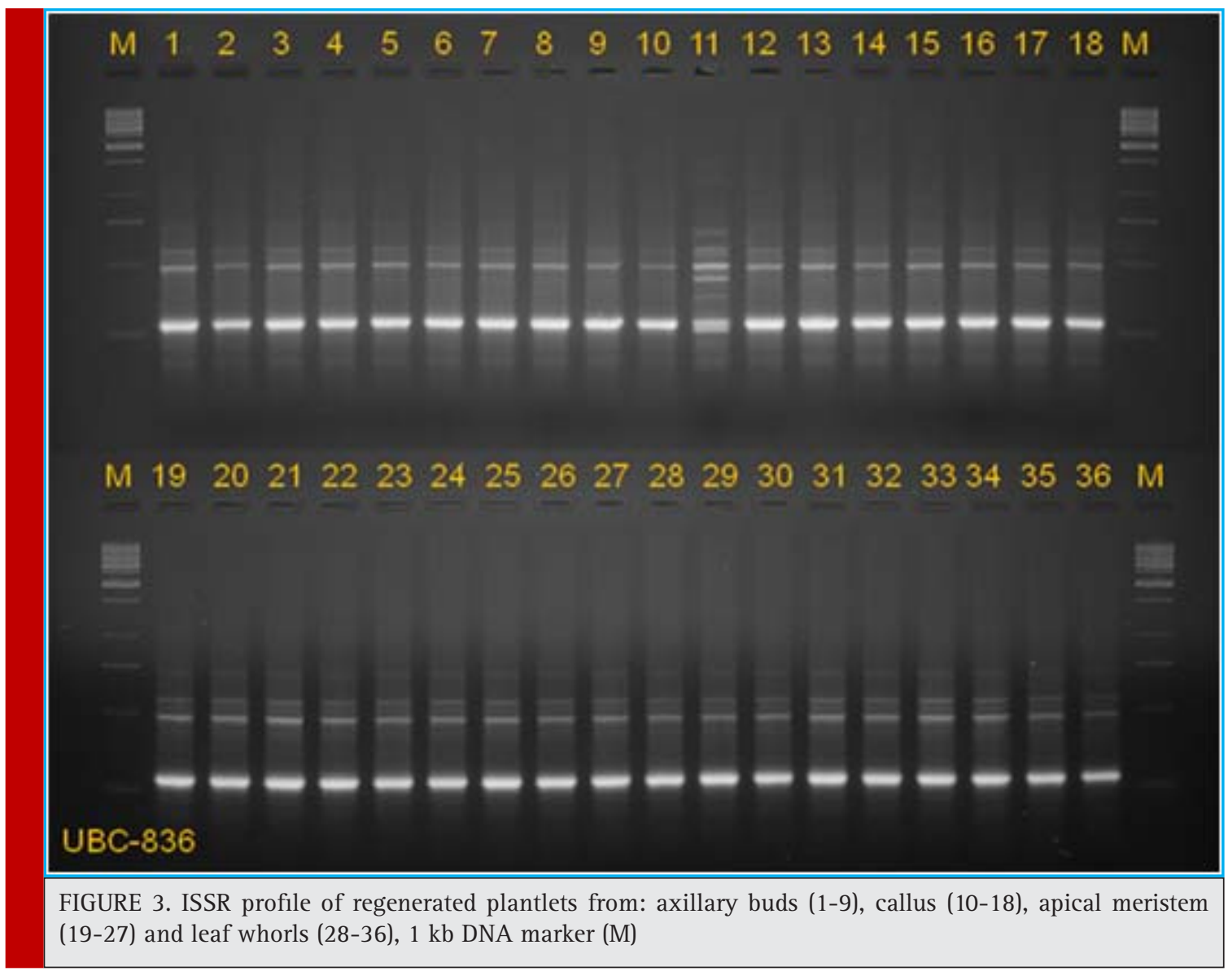

Table 3. Molecular polymorphism analyzed by ISSR markers.

\begin{tabular}{|c|c|c|c|c|c|c|c|c|c|c|c|c|c|c|c|}
\hline \multirow{3}{*}{$\begin{array}{l}\text { Sr. } \\
\text { No }\end{array}$} & \multirow{3}{*}{$\begin{array}{l}\text { Primer } \\
\text { code }\end{array}$} & \multirow{3}{*}{$\begin{array}{l}\text { Primer } \\
\text { sequence } \\
\text { (5' to 3') }\end{array}$} & \multicolumn{9}{|c|}{ Direct organogenesis } & \multirow{2}{*}{\multicolumn{3}{|c|}{$\begin{array}{c}\text { Indirect } \\
\text { organogenesis } \\
\text { Callus culture } \\
\end{array}$}} & \multirow{3}{*}{$\begin{array}{l}\text { Size } \\
\text { range } \\
\text { (bp) }\end{array}$} \\
\hline & & & \multicolumn{3}{|c|}{ Axillary buds } & \multicolumn{3}{|c|}{ Apical meristem } & \multicolumn{3}{|c|}{ Leaf whorl disk } & & & & \\
\hline & & & $n S B$ & $n M B$ & $n P B$ & $n S B$ & $n \mathrm{MB}$ & $n \mathrm{~PB}$ & $n S B$ & $n M B$ & $n \mathrm{~PB}$ & $n S B$ & $n \mathrm{MB}$ & $n \mathrm{~PB}$ & \\
\hline 1 & UBC-817 & (CA)8A & 7 & 7 & 0 & 7 & 7 & 0 & 7 & 7 & 0 & 7 & 7 & 0 & $500-1500$ \\
\hline 2 & UBC-835 & (AG)8YC & 4 & 4 & 0 & 4 & 4 & 0 & 4 & 4 & 0 & 4 & 4 & 0 & $250-1000$ \\
\hline 3 & UBC-836 & (AG)8YA & 4 & 4 & 0 & 4 & 4 & 0 & 4 & 4 & 0 & 7 & 4 & 3 & $500-1000$ \\
\hline 4 & UBC-844 & (CT) $8 \mathrm{RC}$ & 7 & 7 & 0 & 7 & 7 & 0 & 7 & 7 & 0 & 7 & 7 & 0 & $500-2000$ \\
\hline 5 & UBC-849 & (GT)8YA & 6 & 6 & 0 & 6 & 6 & 0 & 6 & 6 & 0 & 6 & 6 & 0 & $500-1000$ \\
\hline 6 & UBC-850 & (GT)8YC & 5 & 5 & 0 & 5 & 5 & 0 & 5 & 5 & 0 & 5 & 5 & 0 & $500-1000$ \\
\hline 7 & UBC-855 & (AC)8YT & 9 & 9 & 0 & 9 & 9 & 0 & 9 & 9 & 0 & 9 & 9 & 0 & $250-3000$ \\
\hline 8 & UBC-857 & (AC)8YG & 6 & 6 & 0 & 6 & 6 & 0 & 6 & 6 & 0 & 6 & 6 & 0 & $250-1000$ \\
\hline 9 & UBC-864 & (ATG)6 & 7 & 7 & 0 & 7 & 7 & 0 & 7 & 7 & 0 & 7 & 7 & 0 & $250-2500$ \\
\hline 10 & UBC-868 & $(\mathrm{GAA}) 6$ & 8 & 8 & 0 & 8 & 8 & 0 & 8 & 8 & 0 & 8 & 8 & 0 & $750-3000$ \\
\hline \multicolumn{3}{|c|}{ Total } & 63 & 63 & 0 & 63 & 63 & 0 & 63 & 63 & 0 & 66 & 63 & 3 & \\
\hline \multicolumn{3}{|c|}{ Percentage (\%) } & & 100 & 0 & & 100 & 0 & & 100 & 0 & & 95.45 & 4.54 & \\
\hline
\end{tabular}


highest numbers of profuse roots in terms of root length were found in the range between 29.33 and $25.33 \mathrm{~mm}$ and number of roots per shoot was ranging from 5.96 to 4.95 (Table 1). Kaur et al. (Kaur and Sandhu, 2015) showing 100\% root induction after 14 days in sugarcane cultivar CoJ 83. Khan et al. (2009) reported that shoots on rooting medium showing $38 \mathrm{~mm}$ in length after 12 days of incubation. The rooting responses in all the cultures are equal and as such no definite differentiations were observed. All the regenerated plants were acclimatized in greenhouse conditions. Around 95\% plants were survived.

The present study was performed to screen the plantlets regenerated from direct shoot organogenesis (axillary buds, apical meristem, and leaf whorl disk) and indirect shoot organogenesis (callus culture) of sugarcane var. Co 86032. PCR-based markers like RAPD and ISSR were employed in genetic fidelity assay. The plants analyzed, representing in-vitro rooted plantlets after $1^{\text {st }}$ multiplication passages. The leaves were collected from these samples randomly. A total of 15 RAPD and 15 ISSR markers were used for preliminary screening with the mother plant of sugarcane. Based on the reproducible band, only 10 of each were selected.

Of the 15 RAPD primer used for the preliminary screening, only 10 primers formed reproducible and scorable banding pattern. These 10 primers produce 38 distinct bands ranging from $1(\mathrm{OPH}-09)$ to 6 (OPH-13 and 18) with an average of 3.8 bands per primer and produced a unique set of amplification product ranging from band size of $250 \mathrm{bp}$ to $3000 \mathrm{bp}$. A total of 1368 bands (No. of plants analyzed from various explants $\times$ No. of band classes with all RAPD primers) was generated in all plantlets from different sections. Primer OPH-09 and OPH-16 amplified the lowest number of one band from each primer. However, $\mathrm{OPH}-13$ and $\mathrm{OPH}-$ 18 amplified the maximum number of 6 bands each. Overall no polymorphism was detected among the plants derived from direct and indirect organogenesis (Table 2). The RAPD profiles of the regenerates are depicted in Fig. 2. Similar results were reported in micro-propagated shoots of Curcuma longa (Salvi et al. 2001), sugarcane (Khan et al. 2009), Gerbera jasmesonii (Bhatia et al. 2011), Momordica dioica (Rai et al. 2012), Terminallia bellerica (Dangi et al. 2014), and Dendrocalamus strictus (Goyal et al. 2015). Zucchi et al. (Zucchi et al. 2002) reported that polymorphism occurred in sugarcane shoots regenerated from meristem cultures because of the number of subcultures and RAPD analysis was used for detection of polymorphism.

Out of 15 ISSR primers used in the preliminary screening, only 10 primers produced clear and reproducible bands. The 10 ISSR primers produced 66 distinct and scorable bands in the size range of 250-3000 $\mathrm{bp}$. The number of scorable bands from for each primed varied from 4 (UBC-835, 836) to 9 (UBC-855), with an average 6.6 bands per primer (Table 3). A total of 2271 bands were generated in all plantlets from different sections. The polymorphism was not occurred in regenerated shoots from axillary buds, apical meristem, and leaf whorl disk during the analysis. Erig and Schuch (2003) and Hsie et al. (2015) observed similar results in sugarcane and showed 100\% true-to-type plantlets. The present results enlighten the fact that plants developed from direct organogenesis are highly stable than those obtained from indirect oraganogenesis (callus) (Kamenickà and Rypák, 1989). However, plant raised from indirect organogenesis (through callus phase) has observed that only one primer (UBC-836) showed three polymorphic and four monomorphic distinct bands (Figure 3). In ISSR primer analysis total $95.45 \%$ monomorphic and remaining 4.55\% polymorphic bands were observed (Table 3). Similar results of polymorphism also observed during micropropagation in Swertia chirayita (Joshi and Dhawan, 2007) and in Gerbera jamesonii (Bhatia et al. 2011).

The possible reasons for polymorphism observed during analysis that occurred in in-vitro raised plantlets regenerated from mother plants using indirect organogenesis might be because of source of application of growth regulators during callus induction, shoot regeneration, duration of cell, and tissue multiplication, accumulating mutations during the process of indirect organogenesis, etc. (Goel et al. 2009; Rizvi et al. 2012; Chavan et al. 2014; Kshirsagar et al. 2015; Thorat et al. 2017). Similarly, ISSR primers were competent to detect polymorphism in Camellia chinensis (Devarumath et al. 2002), Stevia (Martin et al. 2004), Gerbera jamesonii (Bhatia et al. 2011), Tylophora indica (Sharma et al. 2014), Dendrocalamus strictus (Goyal et al. 2016), Morus alba (Saha et al. 2016) and Saccharum officinarum (Thorat et al. 2017).

The regenerated plantlets did not show any measurable dissimilarity in morphology when compared to the respected mother plant. However, sometimes a variation occurs during micropropagation and cannot be observed because the structural difference in the gene product does not always change its biological activity to extend for phenotypic expression. The presence or absence of genetic variation during in-vitro regeneration depends upon the source of the explants and the method of the regeneration (Goto et al. 1998) and finest levels of plant growth substances have also related with somaclonal variation (Martin et al. 2004). RAPD and ISSR are the simple, cost-effective PCR-based techniques used in this study to check the genetic similarity in in-vitro regenerated plants. This marker amplifies the different loci of the genome which allows better chances for identi- 
fication of variation at the genetic level (Martin et al. 2004). Thus, confirmation of the similarity at the genetic level is needful by DNA analysis techniques. Therefore, in this study two DNA-based molecular markers (RAPD and ISSR) were employed for genetic fidelity analysis of both direct and indirect organogenesis derived plantlets of Co86032.

\section{CONCLUSION}

In the present investigation, the molecular study revealed that the micropropagated plants from direct organogenesis were genetically similar with respect to the mother plant and no differentiation was induced during micropropagation and plant regenerated from indirect organogenesis, that is, callus culture found optimum levels leads to somaclonal or epigenetic variation. A plant regenerated from adventitious buds showed the lower tendency for genetic differentiation (Joshi and Dhawan, 2007).Therefore, the routine checkup is necessary to identify the genetic variation of the micropropagated plants and helping to produce true-to-type progeny. Although, RAPD and ISSR has been proved as the most suitable techniques to detect genetic variation provoked during micropropagation (Devarumath et al. 2002; Shu et al, 2003).

\section{ACKNOWLEDGEMENTS}

The authors are grateful to Shri. Shivajirao Deshmukh, Director General, Vasantdada Sugar Institute, Manjari (Bk.), Pune for his constant support, encouragement, and providing all the facilities. One of the Authors (AT) received research fellowship (Late Madhubhau Chaudhari Fellowship) during research work.

\section{REFERENCES}

Aljanabi SM, Forget L, Dookun A (1999) An Improved and Rapid Protocol for the Isolation of Polysaccharide- and Polyphenol-Free Sugarcane DNA. Plant Molecular Biology Reporter 17:281-281

Babu KH, Nerkar YS (2012) Transient GUS expression studies of single and double CaMV35s promoter in sugarcane and comparison with tobacco leaves, and rice callus. Adv. Bio. Tech. 11(9):33-35.

Behara KK, Sahoo S (2009) Rapid in-vitro micro propagation of sugarcane (Saccharum officinarum L. cv-Nayana) through callus culture. Nature and Science 7(4): 1-10

Bhatia R, Singh KP, Sharma TR, Jhang T (2011) Evaluation of the genetic fidelity of in vitro-propagated gerbera (Gerbera jamesonii Bolus) using DNA-based markers Plant Cell Tiss. Org. Cult. 104:131-135.
Ceasar SA, Maxwell SL, Prasad KB, Karthigan M, Ignacimuthu $S$ (2010) Highly efficient shoot regeneration of Bacopa monnieri L. using a two-stage culture procedure and assessment of genetic integrity of micropropagated plants by RAPD. Acta Physiol. Plant. 32:443-452.

Chavan JJ, Gaikwad NB, Umdale SD, Kshirsagar PR, Bhat KV, Yadav SR (2014) Efficiency of direct and indirect shoot organogenesis molecular profiling, secondary metabolite production and antioxidant activity of micropropagated Ceropegia santapaui. Plant Growth Regul 72:1-15

Dangi B, Khurana-Kaul V, Kothari SL, Kachhwaha S (2014) Micropropagtion of Terminalia bellerica from nodal explants of mature tree and assessment of genetic fidelity using ISSR and RAPD markers. Physiol. Mol. Biol. Plants 20:509-516

Das S, Jha TB, Jha S (1996) Stratergies for improving of Cashewnut through Tissue culture. In: Plant Tissue Culture. Islam AS (ed.) Oxford and IBH Publishing Co. Pvt. Ltd. Ltd. 1-7

Devarumath RM, Doule RB, Kawar PG, Naikebawane SB, Nerkar YS (2007) Field performance and RAPD analysis to evaluate genetic fidelity of tissue culture raised plants vis-avis conventional setts derived plants of sugarcane. Sugar Tech 9:17-22

Devarumath RM, Nandy S, Rani V, Marimuthu S, Muraleedharan N, Raina SN (2002) RAPD, ISSR and RFLP fingerprints as useful markers to evaluate genetic integrity of micropropagated plants of three diploid and triploid elite tea clones representing Camellia sinensis (China type) and C. assamica ssp. assamica (Assam-India type). Plant Cell Rep 21:166-173

Erig AC, Schuch MW (2003) Avaliação da fidelida degenotípic apormarcadores RAPDs de brotações de pereira (Pyrus communis L.) cv. Carrick, regeneradas in vitro. Ciênc.Rural. 33: 449-454.

Fildmann P, Sapotille J, Gredoire P, Rott P (1994). Micropropagation of sugarcane. In: Teisson C, ed. In vitro culture of tropical plants. France 15-17.

Gill NK, Gill R, Gosal SS (2004) Factor enhancing somatic embryogenesis and plant regeneration in sugarcane (Saccharum officinarum L.).Indian Journal of Biotechnology. 3: 119123

Gill R, Malhotra PK, Gosal SS (2006) Direct plant regeneration from cultures young leaf segment of sugarcane. Plant Cell, Tissue and Organ Culture 84: 227-231.

Goel MK, Kukreja AK, Bisht NS (2009) In vitro manipulations in St. John's wort (Hypericum perforatum L.) for incessant and scale up micropropagation using adventitious roots in liquid medium and assessment of clonal fidelity using RAPD analysis. Plant Cell Tiss Organ Cult 96:1-9

Goto S, Thakur RC, Ishii K (1998) Determination of genetic stability in long-term micropropagated shoots of Pinus thunbergii Parl. using RAPD markers. Plant Cell Rep 18:193-197

Govindaraj M, Vetriventhan M, Srinivasan M. Importance of Genetic Diversity Assessment in Crop Plants and Its Recent Advances: An Overview of Its Analytical Perspectives. Genetics Research International (2015): 1-14 
Goyal AK, Pradhan S, Basistha BC, Sen A (2015) Micropropagation and assessment of genetic fidelity of Dendrocalamus strictus (Roxb.) nees using RAPD and ISSR markers. 3 Biotech 5:473-482

Hsie BS, Brito JZ, Vila Nova MX, Borges-Paluch LR, Silva MV, Donato VMST (2015) Determining the genetic stability of micropropagated sugarcane using inter-simple sequence repeat markers. Genet. Mol. Res. 14 (4): 17651-17659

Joshi P, Dhawan V (2007) Assessment of genetic fidelity of micropropagated Swertia chirayita plantlets by ISSR marker assay. Biol Plant 51:22-26

Joyce P, Kuwahata M, Turner N, Lakshmanan P (2010) Selection system and co-cultivation medium are important determinants of Agrobacterium-mediated transformation of sugarcane. Plant Cell Reports 29:173-183

Kalunke RM, Kolge AM, Babu KH, Prasad DT (2009) Agrobacterium mediated transformation of sugarcane for borer resistance using Cry1Aa3 gene and one-step regeneration of transgenic plants. Sugar Tech 11(4):355-359

Kamenickà A, Rypák M (1989) The regeneration of Actinidia chinesis Pl. cultured in vitro. Polnohospodarvo 35: 811-818.

Kaur A and Sandhu JS (2015) High throughput in vitro micropropagation of sugarcane (Saccharum officinarum L.) from spindle roll segment: Cost analysis for agri-business industry. Plant Cell Tiss Organ Cult 120: 339-350.

Khan IA, Dahot MU, Seema N, Yasmin S, Bibi S, Raza S, Khatri A (2009) Genetic variability in sugarcane plantlets developed through in vitro mutagenesis. Pak. J. Bot., 41(1): 153-166

Khan SA, Rashid H, Chaudhary MF, Chaudhry Z and Afroz A (2008) Rapid micropropagation of three elite Sugarcane (Saccharum officinarum L.) varieties by shoot tip culture. African Journal of Biotechnology 7(13):2174-2180

Kshirsagar PR, Chavan JJ, Umdale SD, Nimbalkar MS, Dixit GB, Gaikwad NB (2015) Highly efficient in vitro regeneration, establishment of callus and cell suspension cultures and RAPD analysis of regenerants of Swertia lawii Burkill. Biotechnology Reports 6:79-84

Lal M, Singh RK, Srivastava S, Singh N, Singh SP, Sharma ML (2008) RAPD marker based analysis of micropropagated plantlets of sugarcane for early evaluation of genetic fidelity Sugar Tech 10:99-103

Lal N, Singh HN (1994) Sugarcane and its problems: Tissue culture for pure and disease free seed production in sugarcane. Indian sugar 44:847-848.

Martin M, Sarmento D, Oliveira MM (2004) Genetic stability of micropropagated almond plantlets, as assessed by RAPD and ISSR markers. Plant Cell Rep. 23:492-496

Murashige T, Skoog F (1962) A revised medium for rapid growth and bioassay with tobacco tissue culture. Physiol. Plant 15:473-497

Rai GK, Singh M, Rai NP, Bhardwaj DR, Kumar S (2012) In vitro propagation of spine gourd (Momordica dioica Roxb.) and assessment of genetic fidelity of micropropagated plants using RAPD analysis. Physiol. Mol. Bio. Plants 18(3):273-280

Rizvi MZ, Kukreja AK, Bisht NS (2012) Plant regeneration in Chlorophytum borivilianum Sant.et Fernand. from embryogenic callus and cell suspension culture and assessment of genetic fidelity of plants derived through somatic embryogenesis. Physiol. Mol. Bio. Plants 18:253-263

Saha S, Adhikari S, Dey T, Ghosh P (2016) RAPD and ISSR based evaluation of genetic stability of micropropagated plantlets of Morus alba L. variety S-1. Meta Gene 7: 7-15.

Salvi ND, George L, Eapen S (2001) Plant regeneration from leaf base callus of turmeric and random amplified polymorphic DNA analysis of regenerated plants. Plant Cell Tiss Organ Cult 66:113-119

Sawant RA, Tawar PN (2011) Use of sodium hypochlorite as media sterilant in sugarcane micropropagation at commercial scale. Sugar Tech 13(1): 27-35

Sharma MM, Verma RN, Singh A, Batra A (2014) Assessment of clonal fidelity of Tylophora indica (Burm. f.)Merrill "in vitro" plantlets by ISSR molecular markers. Springer Plus 3:400

Shu QY, Liu GS, Qi DM, Chu CC, Liu J, Li HJ (2003) An effective method for axillary bud culture and RAPD analysis of cloned plants in tetraploid black locust. Plant Cell Report 22:175-180

Singh NP, Shami V (2017) Abiotic stress tolerance in sugarcane using genomics and proteomics techniques. In: Kalpana Sengar (ed) Biotechnology to Enhance Sugarcane Productivity and Stress Tolerance. CRC Press, Boca Raton, FL.

Suprasanna P, Patade VY, Desai NS, Devarumath RM, Kawar PG, Pagariya MC, Ganapathi A, Manickavasagam M, Babu KH (2011) Biotechnological developments in sugarcane improvement: An overview. Sugar Tech 13:322-335

Thorat AS, Muley AB, Shingote PR, Nalavade VM, K. H. Babu (2016) Establishment of sterilization method for reducing microbial contamination for emergent quality of sugarcane (Saccharum officinarum L.) in an efficient micropropagation system. Res. J. Pharm. Biol. Chem. Sci. 7(2): 1122-1135.

Thorat AS, Shingote PR, Pal RK, Kharate SB, Nalavade VM, Dhumale DR, Pawar BH, Babu KH (2015). Detection of Sugarcane Mosaic Virus (ScMV) in diseased Sugarcane using ELISA and RT-PCR Technique. Journal of Pure and Applied Microbiology. 9(1):319-327.

Thorat AS, Sonone NA, Choudhari VV, Devarumath RM and K. H.Babu (2017) Plant regeneration from cell suspension culture in Saccharum officinarum L. and ascertaining of genetic fidelity through RAPD and ISSR markers. 3 Biotech (2017) 7: 16. 10.1007/s13205-016-0579-3

Williams JGK, Kuubelik AR, Livak KJ, Rafalski JA, Tingey SV (1990) DNA polymorphisms amplified by arbitrary primers are useful as genetic markers. Nucleic Acids Res 18: 65316535.

Zucchi MI, Arizono H, Morais VA, Fungaro MAP, Vieira MLC (2002) Genetic instability of sugarcane plants derived from meristem cultures. Genetics and Molecular Biology 25(1):91-96 